\title{
C-peptide prevents and improves chronic Type I diabetic polyneuropathy in the BB/Wor rat
}

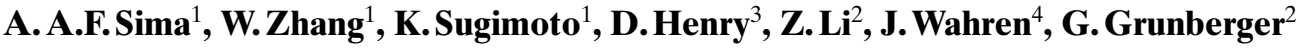 \\ ${ }^{1}$ From the Department of Pathology, Wayne State University, Detroit, Michigan, USA \\ ${ }^{2}$ Center for Molecular Medicine and Genetics, Wayne State University, Detroit, Michigan, USA \\ ${ }^{3}$ Department of Physiology, Michigan State University, East Lansing, Michigan, USA \\ ${ }^{4}$ Department of Clinical Physiology, Karolinska Hospital, Stockholm, Sweden
}

\section{Abstract}

Aims/hypothesis. Insulin and C-peptide exert neuroprotective effects and are deficient in Type I (insulin-dependent) diabetes mellitus but not in Type II (non-insulin-dependent) diabetes mellitus. These studies were designed to test the preventive and interventional effects of $C$-peptide replacement on diabetic polyneuropathy in the Type I diabetic BB/Wor rat. Methods. Diabetic BB/Wor rats were replaced with rat $\mathrm{C}$-peptide from onset of diabetes and between 5 and 8 months of diabetes. They were examined at 2 and 8 months and compared to non-C-peptide replaced BB/Wor rats, Type II diabetic (non-C-peptide deficient) $\mathrm{BB} / \mathrm{Z}$ rats and non-diabetic control rats. Animals were monitored as to hyperglycaemia and nerve conduction velocity (NCV). Acute changes such as neural $\mathrm{Na}^{+} / \mathrm{K}^{+}$-ATPase and paranodal swelling were examined at 2 months, morphometric and teased fiber analyses were done at 8 months.

Results. C-peptide replacement for 2 months in Type I diabetic rats prevented the acute NCV defect by $59 \%(p<0.005)$, the neural $\mathrm{Na}^{+} / \mathrm{K}^{+}$-ATPase defect by $55 \%(p<0.001)$ and acute paranodal swelling by $61 \%(p<0.001)$. Eight months of C-peptide replacement prevented the chronic nerve conduction defect by $71 \%(p<0.001)$ and totally prevented axoglial dysjunction $(p<0.001)$ and paranodal demyelination $(p<0.001)$. C-peptide treatment from 5 to 8 months showed a $13 \%(p<0.05)$ improvement in NCV, a $33 \%(p<0.05)$ improvement in axoglial dysjunction, normalization $(p<0.001)$ of paranodal demyelination, repair of axonal degeneration $(p<0.01)$, and a fourfold $(p<0.001)$ increase in nerve fibre regeneration.

Conclusion/interpretation. C-peptide replacement of Type I BB/Wor-rats partially prevents acute and chronic metabolic, functional and structural changes that separate Type I diabetic polyneuropathy from its Type II counterpart suggesting that C-peptide deficiency plays a pathogenetic role in Type I diabetic polyneuropathy. [Diabetologia (2001) 44: 889-897]

Keywords Diabetic neuropathy, C-peptide, $\mathrm{Na}^{+} / \mathrm{K}^{+}$ATPase, nerve conduction velocity, morphometry.
Diabetic polyneuropathy (DPN) occurs in Type I (insulin-dependent) diabetes mellitus and Type II (noninsulin-dependent) diabetes mellitus and is believed

Corresponding author: Anders A.F. Sima, MD, PhD, Wayne State University, Department of Pathology, Detroit, MI 48201, USA, E-mail: asima@med.wayne.edu

Abbreviations: AGD, Axoglial dysjunction; BB rat, bio-breeding rat, non-diabetes-prone control rat; BB-Wor rat, biobreeding Worcester rat, diabetes-prone Type I rat; BB/Z rat, bio-breeding rat outbred on Zucker background, insulin resistant Type II diabetic rat; C-2, 2-month non-diabetes-prone control rats; C-5, 5-month non-diabetes-prone control rats; C-8, 8-month non-diabetes-prone control rats; D1-2, 2-month to be initiated and fueled by hyperglycaemia. The mechanisms include increased activation of the polyol pathway [1], impaired blood flow, secondary to

Type I diabetic rats; D1-5, 5-month Type I diabetic rats; D1-8, 8-month Type I diabetic rats; D1CP-2, 2-month C-peptide replaced Type I diabetic rats; D1CP-8, 8-month C-peptide replaced Type I diabetic rats; D1CP-5/8, Type I diabetic rats treated with $\mathrm{C}$-peptide between 5 and 8-months of diabetes; D2-2, 2-month Type II diabetic rats; D2-8, 8-month Type II diabetic rats; DPN, diabetic polyneuropathy; NCV, nerve conduction velocity; P13-kinase, phosphatidylinositol 3-kinase; $\mathrm{p} 85$, regulatory domain of P13-kinase. 


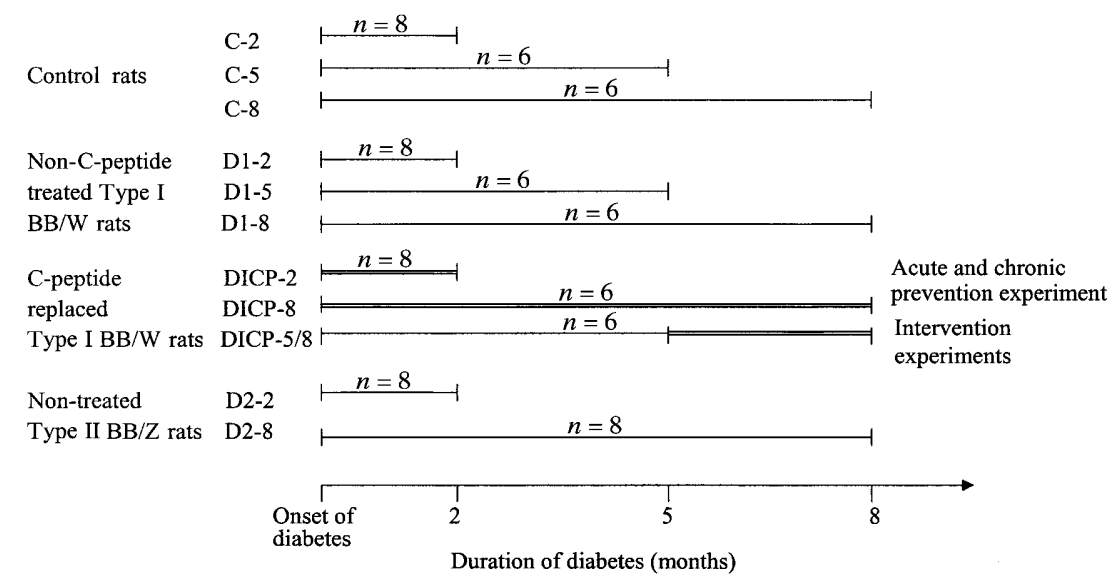

Fig. 1. Flow chart of study design: C-peptide replaced Type I diabetic $\mathrm{BB} / \mathrm{W}$ rats were examined at 2 months (D1CP-2) and 8 months (D1C-P-8). Double lines indicate periods of C-peptide replacement. These groups were compared with age-, sex- and disease-duration-matched non-C-peptide replaced $\mathrm{BB} / \mathrm{W}$ rats (D1-2 and D1-8 respectively), non-diabetic controls (C-2 and C-8 respectively), and age-, sex-, hyperglycaemia-, and disease-duration-matched non-C-peptide deficient Type II diabetic BB/Z rats (D2-2 and D2-8 respectively). Cpeptide treatment was initiated at 5 months of diabetes for a duration of 3 months (D1C-P-5/8; double line). This group was compared with 5 months diabetic (D1-5) and non-diabetic control animals (C-5)

perturbed nitric oxide and prostanoid metabolism [2-4], aberrant regulation of neurotrophic influences [5, 6], non-enzymatic glycation [7], and generation of radical oxygen species $[8,9]$. These abnormalities occur sequentially and are interrelated, resulting in a complex series of pathogenetic components [10].

Recent data show differences between DPN in the two types of diabetes. The Diabetes Control and Complications Trial (DCCT), designed to achieve normoglycaemia in Type I patients, showed only partial prevention of DPN [11]. Comparisons between DPN in rat models of the two types of diabetes show less severe axonal degeneration in Type II models [12-13]. Furthermore, both human and rodent Type II DPN lack the nodal pathology characteristic of Type I DPN [13-15], suggesting that factors besides hyperglycaemia contribute to Type I DPN. These data are consistent with the Rochester Diabetic Neuropathy Study Report [16] showing that Type I diabetes is associated with more severe DPN.

Since both insulin and C-peptide exert neuroprotective effects $[17,18]$, their deficiencies could contribute to Type I DPN. Short time studies have reported beneficial effects of C-peptide on renal, sensory and autonomic abnormalities in Type I diabetic patients $[19,20]$.

We examined the preventive effects of C-peptide replacement on acute and chronic changes of DPN in the C-peptide deficient Type I BB/Wor rat. The effects of C-peptide treatment on chronic functional and structural abnormalities were examined in an intervention study. The data were compared to those of non-diabetic BB rats, non-C-peptide replaced diabetic $\mathrm{BB} /$ Wor rats and non-C-peptide deficient Type II $\mathrm{BB} / \mathrm{Z}$ rats matched for hyperglycaemia and duration of disease.

\section{Materials and methods}

Animals. Forty pre-diabetic male BB/Wor rats and 20 agematched non-diabetes prone BB rats were used (Biomedical Research Models, Worcester, Mass., USA). They were maintained in metabolic cages with free access to water and rat chow. Body weight, urine volume and glucosuria were monitored daily to ascertain onset of diabetes. After onset of diabetes at $71 \pm 3$ days of age, diabetic rats were supplemented with titrated doses (0.5-3.0 U/day) of protamine zinc insulin (Novo Nordisk, Princeton, N.J., USA) [4]. Blood glucose was measured every 2 weeks and glycated haemoglobin (DCA 2000 Analyser, Bayer, and Elkhart, Ind., USA) every 2 months.

One week after onset of diabetes, two groups of diabetic rats were started on $\mathrm{C}$-peptide replacement (prevention groups) for $2(n=8)$ and 8 months $(n=6)$ (D1CP-2 and D1CP-8). They were matched with an equal number of nonC-peptide replaced diabetic rats (D1-2 and D1-8) and agematched non-diabetic control rats (C2 and C8 resp) (Fig. 1). A group of six diabetic rats was started on C-peptide treatment at 5 months and killed at 8 months of diabetes (intervention group; D1CP-5/8). Six non-C-peptide-treated diabetic BB/ Wor rats (D1-5) and 6 age-matched control rats (C-5) were killed at 5 months for baseline controls (Fig. 1). Furthermore, 16 pre-diabetic $\mathrm{BB} / \mathrm{Z}$ rats, with spontaneous onset of Type II diabetes at approximately $70 \mathrm{~d}$ of age, were used as hyperglycaemic non-C-peptide deficient controls for the 2 and 8 month groups (D2-2 and D2-8) (Fig. 1). The animals were cared for in accordance with guidelines of the Animal Investigation Committee, Wayne State University and those of NIH [publication No. 85-23, 1995].

C-peptide replacement. Synthetic rat C-peptide II, with a purity of more than $98 \%$ by HPLC (Genosys, Cambridge, UK) was dissolved in saline $(12 \mathrm{mg} / \mathrm{ml})$. Osmopumps (Alzet Corporation, Palo Alto, Calif., USA) delivered a minimum subcutaneous dose of $75 \mathrm{nmol}$ C-peptide/kg body weight a day. Control rats and non-C-peptide replaced diabetic rats received osmopumps with saline alone. 
Table 1. Biochemical, functional and morphometric data from 2 month Type I (D1-2), Type II (D2-2), C-peptide replaced Type I (D1CP-2) and control rats (C-2)

\begin{tabular}{lcllll}
\hline Animal groups & $\begin{array}{l}\mathrm{Na}^{+} / \mathrm{K}^{+}-\mathrm{ATPase} \\
(\mu \mathrm{mol} \text { ADP/mg } \\
\text { weight per hour) }\end{array}$ & $\begin{array}{l}\text { Nerve Conduction } \\
\text { velocity }(\mathrm{m} / \mathrm{sec}) \\
(95 \% \text { Conf. })\end{array}$ & $\begin{array}{l}\text { Paranodal swelling (\%) } \\
(95 \% \text { Conf.) }\end{array}$ & $\begin{array}{l}\text { Axonal Area }\left(\mu m^{2}\right) \\
(95 \% \text { Conf.) }\end{array}$ & $\begin{array}{l}\text { Axon:myelin ratio } \\
(95 \% \text { Conf.) }\end{array}$ \\
\hline C-2 $(n=8)$ & $149 \pm 23$ & $61.8 \pm 1.4[0.74]$ & $1.4 \pm 0.3[0.82]$ & $11.1 \pm 1.8[1.18]$ & $0.64 \pm 0.07[0.05]$ \\
D1-2 $(n=8)$ & $42 \pm 19^{\mathrm{a}}$ & $44.0 \pm 3.1^{\mathrm{a}}[1.56]$ & $8.0 \pm 0.9^{\mathrm{a}}[1.25]$ & $12.9 \pm 1.5[1.51]$ & $0.81 \pm 0.06^{\mathrm{c}}[0.13]$ \\
D1CP-2 $(n=8)$ & $101 \pm 14^{\mathrm{a}, \mathrm{d}}$ & $52.6 \pm 2.0^{\mathrm{b}, \mathrm{e}}[1.01]$ & $3.9 \pm 0.5^{\mathrm{b}, \mathrm{d}}[1.21]$ & $11.3 \pm 1.5[1.67]$ & $0.71 \pm 0.06[0.06]$ \\
D2-2 $(n=8)$ & $82 \pm 7^{\mathrm{a}, \mathrm{d}}$ & $55.0 \pm 2.1^{\mathrm{b}, \mathrm{e}}[1.11]$ & $2.4 \pm 0.6^{\mathrm{c}, \mathrm{d}}[1.24]$ & $11.3 \pm 1.1[1.42]$ & $0.60 \pm 0.12[0.09]$ \\
\hline
\end{tabular}

${ }^{\mathrm{a}} p<0.001 ;{ }^{\mathrm{b}} p<0.01 ;{ }^{\mathrm{c}} p<0.05 \mathrm{vs} \mathrm{C}-2$ rats,

${ }^{\mathrm{d}} p<0.001 ;{ }^{\mathrm{e}} p<0.005$ vs D1-2 rats

Electrophysiological studies. Baseline nerve conduction velocity (NCV) was measured within $24 \mathrm{~h}$ of onset of diabetes. It was measured in the sciatic-tibial nerves under temperature-controlled $\left(35^{\circ} \mathrm{C}-37^{\circ} \mathrm{C}\right)$ conditions $[4,13]$.

Tissue collection. Animals were anaesthetized with Na-pentobarbital $(50 \mathrm{mg} / \mathrm{kg}$ body weight i.p.) and both sciatic nerves were dissected, weighed and snap-frozen in liquid nitrogen for measurements of nerve glucose, sorbitol, fructose and $\mathrm{Na}^{+} /$ $\mathrm{K}^{+}$-ATPase activity. The right sural nerve was fixed in $2.5 \%$ glutaraldehyde in $0.1 \mathrm{~mol} / \mathrm{l}$ cacodylate buffer at $\mathrm{pH} 7.40$, and post-fixed in $1 \%$ osmium tetroxide ( $\mathrm{pH} 7.40)$. Cross-sections and longitudinal sections of the proximal sural nerve were embedded in Epon for morphometric assessments. The distal sural nerve was used for teased fibre preparations [13, 15]. Cardiac blood was drawn for serum insulin and C-peptide concentrations between 8:00 and 10:00 am, 18 to 20 hours after the last insulin injection.

Insulin and C-peptide concentrations. Serum insulin and Cpeptide concentrations were examined using commercially available RIA kits (Linco Research, St. Charles, Mo., USA).

Biochemical analyses. For nerve glucose, sorbitol and fructose, sciatic nerve samples were homogenized in $2 \mathrm{ml}$ of $5 \%$ TCA. Aldonitrile derivatives were formed by adding $0.3 \mathrm{ml}$ hydroxylamine in pyridine-methanol 4:1 (vol:vol). Samples were sonicated for $1 \mathrm{~min}$ and $1 \mathrm{ml}$ of acetic anhydride and $2 \mathrm{ml}$ of 1,2 dichlorothane were added and samples were washed in $1.0 \mathrm{~N}$ $\mathrm{HCl}$. Samples were reconstituted in 2-butanane and analysed by gas-liquid chromatography [21].

For $\mathrm{Na}^{+} / \mathrm{K}^{+}$-ATPase activity, nerve samples were homogenized in $2 \mathrm{ml}$ of $0.2 \mathrm{~mol} / \mathrm{l}$ sucrose and $0.02 \mathrm{~mol} / \mathrm{l} \mathrm{TRIS}-\mathrm{HCl}$ at pH 7.5. Between 10 and $20 \mu$ l of the homogenate was assayed enzymatically for total ATPase in $1 \mathrm{ml}$ of $100 \mathrm{mmol} / \mathrm{l} \mathrm{NaCl}$, $10 \mathrm{mmol} / \mathrm{l} \mathrm{KCl}, 2.5 \mathrm{mmol} / \mathrm{l} \mathrm{MgCl}_{2}, 1 \mathrm{mmol} / \mathrm{l}$ TRIS ATP, $1 \mathrm{mmol} / \mathrm{l}$ phosphoenolpyruvate, $30 \mathrm{mmol} / \mathrm{l}$ imidazole $\mathrm{HCl}$ buffer ( $\mathrm{pH} 7.30), 0.15 \mathrm{mmol} / \mathrm{l} \mathrm{NADH}, 50 \mu \mathrm{g}$ lactate dehydrogenase and $30 \mu \mathrm{g}$ pyruvate kinase [4]. To measure ouabain-inhibited ATPase, $20 \mu \mathrm{l}$ of $25 \mathrm{mmol} / \mathrm{l}$ of ouabain was added. $\mathrm{Na}^{+} /$ $\mathrm{K}^{+}$-ATPase activity was defined as the difference before and after ouabain and was expressed as $\mu$ mol ADP formed per gram of wet weight per hour.

Morphometric analysis. Semithin $(0.5 \mu \mathrm{m})$ cross-sections of sural nerves were used for morphometric analysis. The following measurements of myelinated fibres were obtained: total number, axonal and myelin size $\left(\mu \mathrm{m}^{2}\right)$, fibre density $\left(n / \mathrm{mm}^{2}\right)$, coefficient of variance $(\mathrm{CV})$ of fibre densities between image frames, fibre occupancy ( $\%$ of endoneurial area), and axon to myelin ratio [4].
Teased fibre examinations. A mean of $168 \pm 4$ myelinated fibres were teased from each sural nerve and scored for specific changes [4]. The temporal sequence and increasing severity are represented by normality, paranodal swelling, paranodal demyelination, excessive myelin wrinkling, intercalated internodes, segmental demyelination, Wallerian degeneration, and regeneration. Changes were expressed as percentages of total fibres.

Assessment of axoglial dysjunction (AGD). The frequency of AGD was examined electron-microscopically from a mean of $18.2 \pm 1.7$ paranodes in each nerve [22]. The frequency of myelin loops devoid of axoglial junctions was expressed as a percentage of the myelin loops examined.

Statistical analysis. The results are presented as means \pm SD and the significance of differences was calculated by analysis of variance (ANOVA). Group differences were assessed by post hoc analysis using the Student-Newman-Keuls test. Tissue samples for biochemical, morphometric and teased fiber analyses were coded to mask animal identity. A $p$ value of less than 0.05 was considered statistically significant.

\section{Results}

Acute preventive effects of 2 months $C$-peptide replacement (Table 1). C-peptide replacement of acutely diabetic rats (DICP-2) restored serum C-peptide concentrations to $74 \%(p<0.001)$ of normal $(\mathrm{C}-2$, $710 \pm 52 ; \quad \mathrm{D} 1-2,43 \pm 12 ; \mathrm{D} 1 \mathrm{CP}-2,527 \pm 40 ;$ and D2-2, $741 \pm 21 \mathrm{pmol} / \mathrm{l})$. It had no effect on serum insulin $(\mathrm{C}-2,455 \pm 52 ; \mathrm{D} 1-2,57 \pm 7$; DlCP-2, $63 \pm 11$; and D2-2, $579 \pm 69 \mathrm{pmol} / \mathrm{l})$ blood glucose, insulin requirements or body weight (data not shown) compared to D1-2 rats. Blood glucose concentrations were: $\mathrm{C}-2, \quad 5.0 \pm 0.4 ; \quad \mathrm{D} 1-2, \quad 19.3 \pm 3.1 ; \quad \mathrm{DlCP}-2$, $20.3 \pm 3.8$; and D2-2, $25.8 \pm 0.8 \mathrm{mmol} / \mathrm{l}$. Nerve glucose, sorbitol or fructose concentrations were not effected (data not shown). Compared with D1-2 rats, C-peptide significantly $(p<0.005)$ prevented the NCV slowing and partially $(p<0.001)$ prevented the $\mathrm{Na}^{+} / \mathrm{K}^{+}$-ATPase defect (Table 1 ). $\mathrm{Na}^{+} / \mathrm{K}^{+}$-ATPase was not different from D2-2 rats (Table 1) nor was NCV in DICP-2 rats different from D2-2 rats, suggesting that parts of the acute $\mathrm{Na}^{+} / \mathrm{K}^{+}$-ATPase and NCV defects are not related to hyperglycaemia but are C-peptide responsive. Paranodal swelling was 


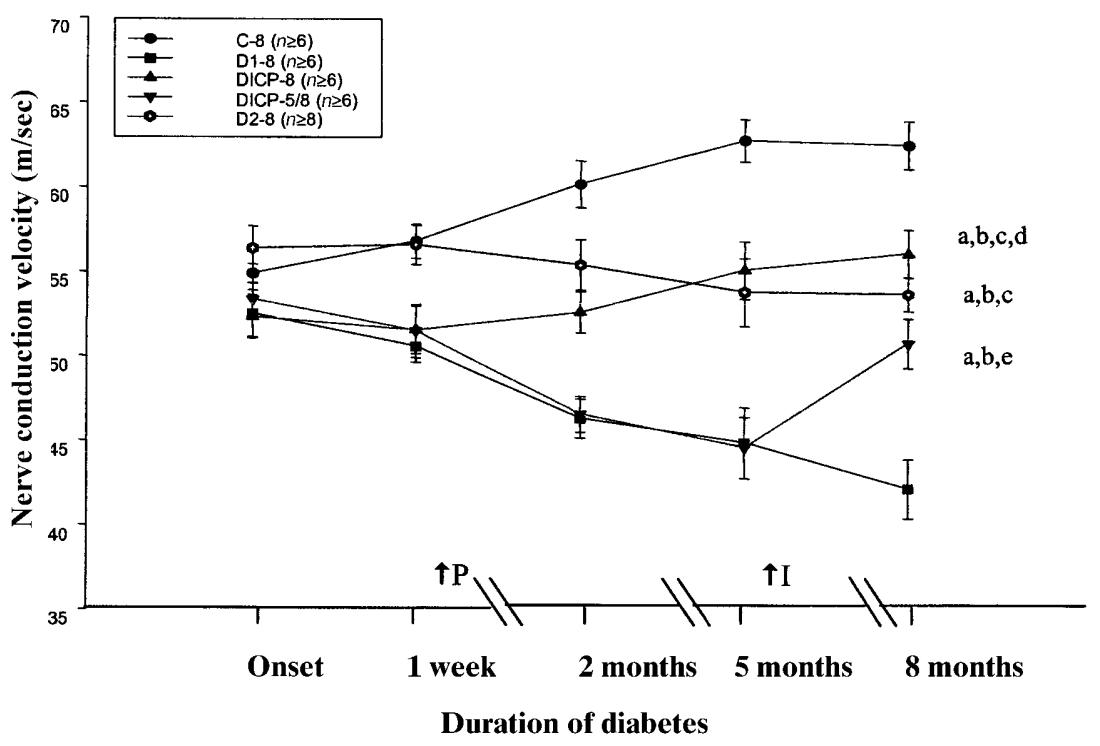

Fig. 2. Nerve conduction velocities (NCV's): Type I diabetic rats showed a severe progressive NCV slowing. C-peptide replacement initiated at 1 week $(\uparrow \mathrm{P})$, not only prevented further NCV slowing but improved NCV $(p<0.05)$. Intervention with $\mathrm{C}$-peptide initiated at 5 months ( $\uparrow \mathrm{I})$, resulted in a significant $(p<0.05)$ improvement of NCV at 8 months. This was slower than in D1CP-8 rats $(p<0.05)$. Type II diabetic rats showed a milder slowing of NCV, which at 8 months was not different from that in D1CP-8 rats; $\uparrow \mathrm{P}$, initiation of C-peptide replacement in the prevention groups; $\uparrow \mathrm{I}$, initiation of C-peptide treatment in the intervention group; ${ }^{\mathrm{a}} p<0.001$ vs age-matched control rats; ${ }^{\mathrm{b}} p<0.001$ vs D1-8 rats; ${ }^{\mathrm{c}} p<0.05$ vs DICP-5/8 rats; ${ }^{\mathrm{d}} p<0.05$ vs $\mathrm{C}$-peptide replacement starting point ( $\left.\uparrow \mathrm{P}\right)$ at $1 \mathrm{wk}$; ${ }^{\mathrm{e}} p<0.05$ vs C-peptide treatment starting point at 5 months $(\uparrow \mathrm{I})$

partially, but significantly $(p<0.001)$ prevented by Cpeptide and was not different from D2-2 rats (Table 1). Paranodal swelling in D1-2 rats was reflected by a significant $(p<0.05)$ increase in axon to myelin ratio (Table 1 ). Other parameters of axonal degeneration were not affected by diabetes or by C-peptide at this stage.

The preventive effect of C-peptide on chronic functional and structural changes. Over the subsequent
6 months, nerve conduction velocity improved $(p<0.05)$ in $\mathrm{D} 1 \mathrm{CP}-8$ rats compared to the values at 1 week (Fig. 2). Compared to D1-8 rats, there was a significant $(p<0.001)$ but partial prevention of NCV slowing. The residual NCV defect $(p<0.001)$ was not different from D2-8 rats (Fig. 2), suggesting a hyperglycaemic and a C-peptide responsive component of the NCV defect [13].

D1-8 rats showed loss of myelinated fibres not evident in D1CP-8 rats (Table 2). Axonal size and axonto-myelin ratios were decreased $(p<0.001$ and $p<0.05)$ in D1-8 compared to C-8 rats. C-peptide prevented $(p<0.01)$ axonal atrophy, which was not different from that in D2-8 rats (Table 2). These findings correlate with teased fibre scoring of axonal degeneration. In D1-8 rats $17 \%$ of sural nerve fibres showed axonal degeneration (Fig. 3), which was significantly $(p<0.001)$ prevented by $\mathrm{C}$-peptide to $4.8 \%$. This was greater $(p<0.01)$ than $1.8 \%$ seen in C-8 rats (Fig. 3 ) but not different from $6.7 \%$ seen in D2-8 rats (Fig. 3).

Axoglial dysjunction and subsequent paranodal demyelination are repaired by remyelination forming intercalated internodes [4]. Axoglial dysjunction was increased 3.5 -fold $(p<0.001)$ in D1-8 but not in

Table 2. Morphometric data from 5 month control rats (C-5) and Type I diabetic (D1-5), 8 month control (C-8), Type I (D1-8) and Type II (D2-8) diabetic, and C-peptide replaced (D1CP-8) diabetic and treated (D1CP-5/8) Type I diabetic rats

\begin{tabular}{lllll}
\hline Animal groups & $\begin{array}{l}\text { Fiber number } \\
(n)\end{array}$ & $\begin{array}{l}\text { Fiber density } \\
\left(n / \mathrm{mm}^{2}\right)\end{array}$ & $\begin{array}{l}\text { Axonal area } \\
\left(\mu \mathrm{m}^{2}\right)\end{array}$ & $\begin{array}{l}\text { Axon/myelin ratio } \\
\left(\mu \mathrm{m}^{2} / \mu \mathrm{m}^{2}\right)\end{array}$ \\
\hline C-8 $(n=6)$ & $810 \pm 59$ & $16268 \pm 1314$ & $14.7 \pm 0.3$ & $0.62+0.2$ \\
D1-8 $(n=6)$ & $589 \pm 56^{\mathrm{b}}$ & $13981 \pm 775^{\mathrm{c}}$ & $12.0 \pm 0.4^{\mathrm{a}}$ & $0.55 \pm 0.03^{\mathrm{b}}$ \\
DICP-8 $(n=6)$ & $751 \pm 84^{\mathrm{f}}$ & $15335 \pm 687$ & $13.9 \pm 0.5^{\mathrm{d}}$ & $0.60 \pm 0.03$ \\
C-5 $(n=6)$ & $789 \pm 76$ & $15736 \pm 776$ & $14.9 \pm 0.3$ & $0.59 \pm 0.02$ \\
D1-5 $(n=6)$ & $731 \pm 92$ & $16411 \pm 611$ & $14.1 \pm 0.7$ & $0.55+0.02^{\mathrm{b}}$ \\
DICP-5/8 $(n=6)$ & $730 \pm 69$ & $16357 \pm 906^{\mathrm{e}}$ & $14.2 \pm 0.5^{\mathrm{d}}$ & $0.58 \pm 0.03$ \\
D2-8 $(n=6)$ & $801 \pm 71^{\mathrm{e}}$ & $16491 \pm 657^{\mathrm{e}}$ & $14.1 \pm 0.5^{\mathrm{d}}$ & $0.59 \pm 0.03$ \\
\hline
\end{tabular}

${ }^{\mathrm{a}} p<0.001 ;{ }^{\mathrm{b}} p<0.05 ;{ }^{\mathrm{c}} p=0.07$ vs C-8 rats;

${ }^{\mathrm{d}} p<0.01 ;{ }^{\mathrm{e}} p<0.05 ;{ }^{\mathrm{f}} p=0.07$ vs D1-8 rats 


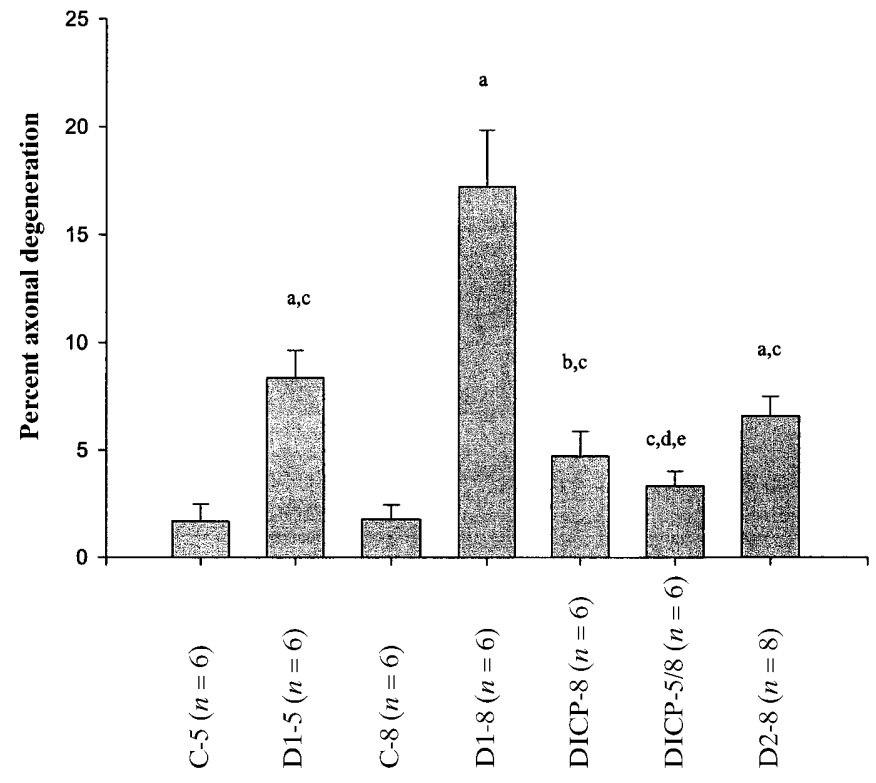

Fig. 3. Teased fiber assessment of axonal degeneration: C-peptide replacement for 8 months (D1C-peptide-8) showed a marked protection $(p<0.001)$ against axonal degeneration, and C-peptide treatment (D1CP-5/8) resulted in a significant $(p<0.001)$ repair of axonal degeneration compared to D1-5 rats. Axonal degeneration in D1C-peptide- 8 rats was not different from that in D2-8 rats, and it was less frequent $(p<0.05)$ in $\mathrm{D} 1 \mathrm{C}$-peptide-5/8 compared to D2-8 rats. ${ }^{\mathrm{a}} p<0.001 ;{ }^{\mathrm{b}} p<0.01$ vs age-matched control rats; ${ }^{\mathrm{c}} p<0.001$ vs D1-8 rats; ${ }^{\mathrm{d}} p<0.001$ vs D1-5 rats; ${ }^{\mathrm{e}} p<0.05$ vs $\mathrm{D} 2-8$ rats

D2-8 rats (Fig. 4A). C-peptide prevented $(p<0.001)$ axoglial dysjunction so that no differences could be shown between D1CP-8, D2-8 and C-8 rats (Fig. 4A). Paranodal demyelination was increased more than eightfold in D1-8 rats $(p<0.001)$ and was prevented by $\mathrm{C}$-peptide $(p<0.001)$ and was not different from C-8 or D2-8 rats (Fig. 4B). Compared to C-8 rats, D1-8 rats showed a threefold increase in intercalated internodes $(p<0.001)$ (Fig. 4C). This was

Fig. 4. The effect of C-peptide on nodal changes: C-peptide replacement (D1CP-8) for 8 months prevented AGD which was not different from that in $\mathrm{C}-8$ or D2-8 rats (A). Intervention with C-peptide (D1CP-5/8) repaired significantly AGD $(p<0.05)$ (A). AGD proceeds to paranodal demyelination (B). C-peptide prevented (D1CP-8) completely $(p<0.001)$ paranodal demyelination (B). Intervention with C-peptide (D1CP-5/8) not only halted the progressive paranodal demyelination but significantly $(p<0.001)$ improved it compared to D1-5 rats $(\mathbf{B})$. Intercalated internodes in $\mathrm{D} 1 \mathrm{CP}-5 / 8$ rats, were significantly $(p<0.05)$ more frequent than in D1-5 rats (C). Intercalated nodes were not increased in D1CP-8 rats (Fig. 4c), probably because of preceding AGD and paranodal demyelination $(\mathbf{A}, \mathbf{B})$ were fully prevented by $\mathbf{C}$-peptide. These nodal changes do not occur in Type II $\mathrm{BB} / \mathrm{Z}$ rats (A-C). ${ }^{\mathrm{a}} p<0.001 ;{ }^{\mathrm{b}} p<0.005 ;{ }^{\mathrm{c}} p<0.05$ vs age-matched control rats; ${ }^{\mathrm{d}} p<0.001$; ${ }^{\mathrm{e}} p<0.01$; ${ }^{\mathrm{f}} p<0.05$ vs D1-8 rats; ${ }^{\mathrm{g}} p<0.001$ vs D1CP-5/8 rats; ${ }^{\mathrm{h}} p<0.001 ;{ }^{\mathrm{i}} p<0.05$ vs D $1-5$ rats
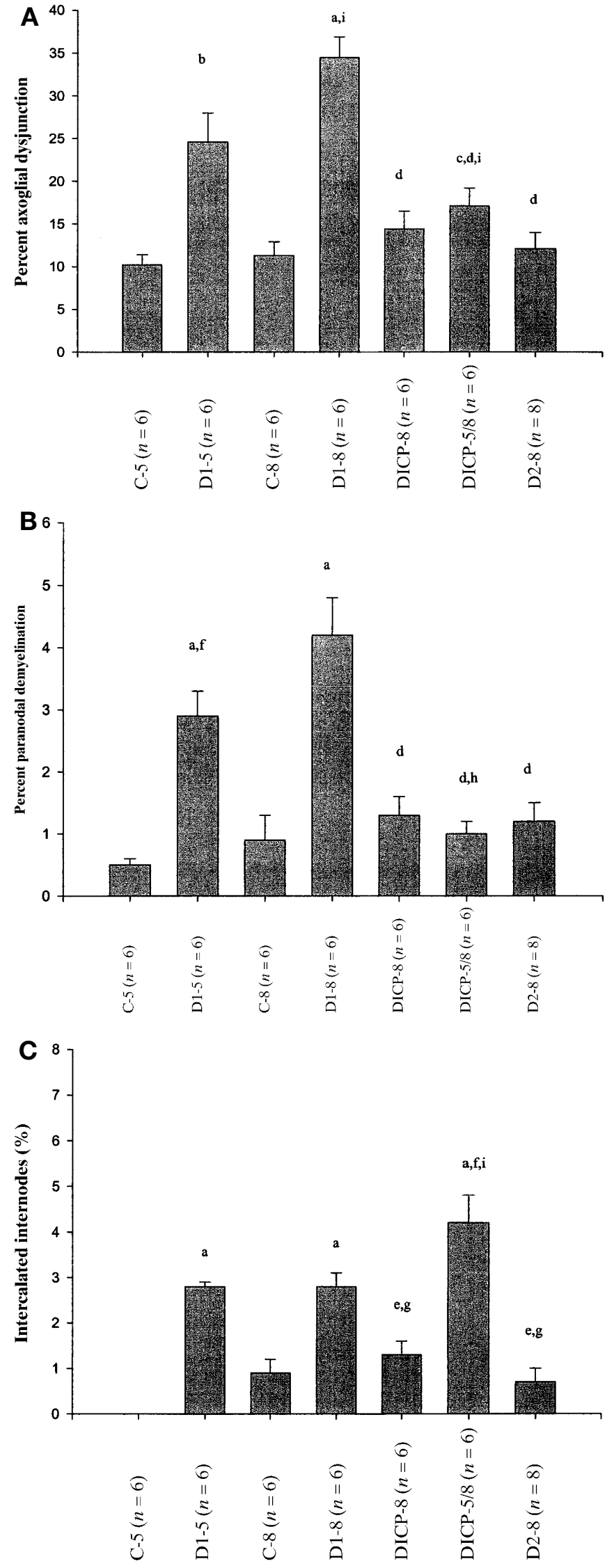


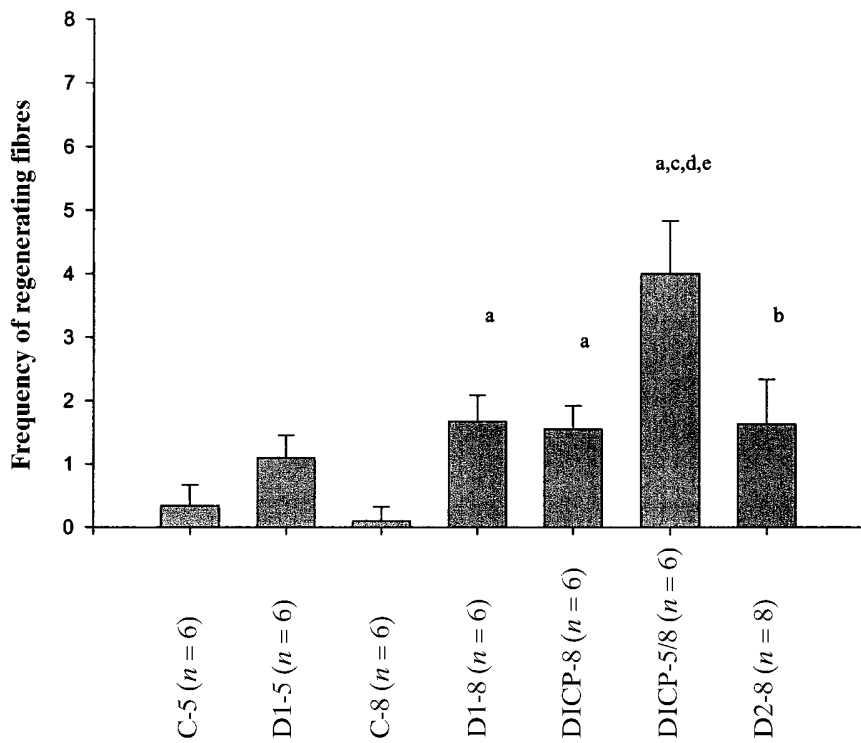

Fig.5. Nerve fibre regeneration: regenerating fibres in $\mathrm{D} 1 \mathrm{CP}$ 8 rats were not different from D1-8 or D2-8 rats. However, C-peptide-treated rats (D1CP-5/8) showed a marked increase $(p<0.001)$ in fibre regeneration compared to D1-5 rats. ${ }^{\mathrm{a}} p<0.001,{ }^{\mathrm{b}} p<0.05$ vs age-matched control rats; ${ }^{\mathrm{c}} p<0.001$ vs D1-8 rats; ${ }^{\mathrm{d}} p<0.001$ vs D1-5 rats; ${ }^{\mathrm{e}} p<0.01$ vs D2-8 rats

prevented $(p<0.001)$ by C-peptide, which was expected, since preceding axoglial dysjunction and paranodal demyelination were prevented by C-peptide. No difference was found between intercalated nodes in D1CP-8, D2-8 and C-8 rats (Fig. 4C).

Regenerating fibres in D1-8 rats was increased $(p<0.001)$ compared to $\mathrm{C}-8$ rats as were those in D2-8 rats $(p<0.05)$ (Fig. 5). C-peptide resulted in an increase $(p<0.001)$ in fibre regeneration compared to $\mathrm{C}-8$ rats but was not different from D1-8 rats (Fig. 5).

The intervention effects of C-peptide treatment. The $\mathrm{NCV}$ in D1-8-rats showed a progressive decline. At 5 months there was a $30 \%$ decrease $(p<0.001)$ in NCV compared to C-5 rats (Fig. 2). C-peptide treatment initiated at this timepoint resulted in a recovery $(p<0.05)$ of the $\mathrm{NCV}$ defect in D1CP-5/8 rats (Fig. 2). It was not normalized $(p<0.001)$ but improved $(p<0.001)$ compared to D1-8 rats but remained slower $(p<0.05)$ than in D1CP-8 and D2-8 rats (Fig. 2).

At 5 months of diabetes, no significant changes were found in myelinated fibre number, density, axonal size or axon-to-myelin ratio (Table 2). However, C-peptide treatment from 5 to 8 months prevented the ensuing decrease in fibre loss $(p<0.05)$ and axonal atrophy $(p<0.01)$ (Table 2$)$. Compared to Type II diabetic $\mathrm{BB} / \mathrm{Z}$ rats, no significant differences could be shown between D2-8 and D1C-peptide-5/8 rats in fibre number, density, axonal area or axon-to-myelin ratio (Table 2).
The more sensitive teased fibre analyses showed an increase $(p<0.001)$ in axonal degeneration in D1-5 rats compared to controls (Fig. 3). C-peptide resulted in a $60 \%(p<0.001)$ repair of axonal degeneration (Fig. 3). Compared to D1-8 rats, axonal degeneration was reduced by $80 \%(p<0.001)($ Fig. 3$)$ and was less than in D2-8 rats $(p<0.05)$.

In D1-5 rats, axoglial dysjunction was increased 2.5 -fold $(p<0.01)$ (Fig. 4A), paranodal demyelination sixfold $(p<0.001)$ (Fig. 4B) as well as intercalated internodes $(p<0.001)$ (Fig. 4C). Intervention with $\mathrm{C}$-peptide resulted in a $50 \%(p<0.05)$ reduction of axoglial dysjunction, which was not different from that in D1CP-8 or D2-8 rats (Fig. 4A) but was not normalized $(p<0.05)$. Paranodal demyelination showed a complete $(p<0.001)$ recovery, and was not different from C-8, D1CP-8 or D2-8 rats (Fig. 4B). In contrast, intercalated internodes showed a $46 \%$ $(p<0.05)$ increase in D1CP-5/8 compared to D1-5 rats and was more common than in D1-8 $(p<0.05)$, D1CP-8 and D2-8 rats (both $p<0.001$ ) (Fig. 4C). Because intercalated internodes reflect a reparative change, these findings suggest that C-peptide promotes remyelination of demyelinated nodes.

Nerve fiber regeneration, the ultimate reparative response, was not significantly increased in D1-5 rats compared to controls and not different from D1-8 or D2-8 rats (Fig. 5). However, C-peptide resulted in a fourfold $(p<0.001)$ increase compared to D1-5 rats, and was greater than in D1-8 $(p<0.001)$ or D2-8 rats $(p<0.01)$ (Fig. 5$)$.

\section{Discussion}

Until recently, the view was held that C-peptide does not exert biological effects on its own, apart from its role in insulin synthesis [23]. However, C-peptide treatment of Type I diabetic patients improves renal function [20], increases blood flow, augments glucose utilization, and improves autonomic and somatic nerve function [18-20]. These beneficial effects correlate with stimulation of $\mathrm{Na}^{+} / \mathrm{K}^{+}$-ATPase and endothelial nitric oxide synthase activities $(18,24,25,31)$.

A C-peptide receptor has not been identified. However, C-peptide binds specifically to cell surfaces [26] with subsequent activation of $\mathrm{Ca}^{2+}$ dependent intracellular signalling pathways $[25,26]$. No cross-reactivity with insulin, pro-insulin of IGF-1 and IGF2 have been observed [25]. We have shown that Cpeptide phosphorylates the insulin receptor and IRS- 1 and inhibits protein tyrosin phosphatase while stimulating glycogen synthesis in L6 myoblasts [27]. This points to an insulinomimetic effect, without competing with insulin at the receptor level, suggesting a different ligand site.

We show significant effects of C-peptide replacement on DPN in the insulin and C-peptide deficient 
Type I diabetic BB/Wor rat. C-peptide showed beneficial effects on the acute NCV, metabolic and structural changes. Long-term prevention and intervention with C-peptide partially prevented and improved the chronic NCV defect and degenerative changes of myelinated fibers, producing a functional and structural DPN similar to that in hyperglycaemia and duration-matched non-C-peptide deficient $\mathrm{BB} / \mathrm{Z}$ rats [13]. This suggests that in Type I DPN one component can be ascribed to hyperglycaemia as in Type II DPN and that an additional component is linked to C-peptide deficiency.

C-peptide replacement resulted in a partial correction of the acute $\mathrm{Na}^{+} / \mathrm{K}^{+}$-ATPase defect, consistent with the reported metabolic effects of C-peptide [18, 24]. Decreased $\mathrm{Na}^{+} / \mathrm{K}^{+}$-ATPase activity is associated with increased inactivation of $\mathrm{Na}^{+}$-channels and intraaxonal $\mathrm{Na}^{+}$accumulation at the node [28], resulting in paranodal swelling [29]. Paranodal swelling was prevented by $61 \%$ in keeping with the partial prevention of the $\mathrm{Na}^{+} / \mathrm{K}^{+}$-ATPase defect. Impaired $\mathrm{NCV}$ in DPN is believed to be caused by impaired blood flow [30], or increased polyol-pathway activity [1], both affecting $\mathrm{Na}^{+} / \mathrm{K}^{+}$-ATPase [8]. C-peptide has a corrective effect on nitric oxide [31] and it could improve nerve blood flow and the acute NCV defect [3, $8,9]$. The residual $\mathrm{NCV}$ and $\mathrm{Na}^{+} / \mathrm{K}^{+}$-ATPase defects, not responsive to $\mathrm{C}$-peptide replacement, could be accounted for by the unaffected activation of the polyol pathway $[1,32]$.

One of the most profound effects of C-peptide was the prevention and repair of nodal and paranodal changes in Type I DPN, changes which separate it from Type II DPN. These findings are likely to explain the partial prevention and improvement of the chronic NCV defect, since nodal changes correlate closely with the NCV deficit [15]. These effects could be more than coincidental because the insulin receptor in peripheral nerves co-localizes with axoglial junctions [33]. It is conceivable that $\mathrm{C}$-peptide via its insulinomimetic effects could regulate molecules important for the nodal integrity, such as ankyrin $_{\mathrm{G}}$, caspr and caspr II [34-36]. p85 of P13-kinase binds via its $\mathrm{SH} 3$ domains to the proline-rich sequence of the caspr protein, suggesting that insulin signalling intermediaries regulate nodal protein-protein interactions [37]. Beside their involvement in the nodal barrier function in itself, these molecules are responsible for the nodal localization of $\mathrm{Na}^{+} / \mathrm{K}^{+}$-ATPase, $\mathrm{Na}^{+}$-channels, and $\mathrm{K}^{+}$-channels [34-36], which are altered or displaced in Type I DPN [10, 38]. Axoglial dysjunction proceeds to paranodal demyelination, which is repaired by intercalated internodes. In the intervention group, prevention of axoglial dysjunction prevented further paranodal demyelination and residual paranodal demyelination at 5 months was likely repaired as reflected by the increased frequency of intercalated internodes.
Eight months of C-peptide replacement prevented axonal atrophy and degeneration. Progressive axonal degeneration in Type I DPN is in part due to impaired neurotrophic support [39] by NGF and IGF1 , which show reduced expression in diabetic rodents [39-41]. Nerve growth factor, IGF-1 and insulin promote the synthesis of neurofilaments [42, 43], which are structural determinants for axonal size [44]. It is conceivable that the insulinomimetic effects of Cpeptide has a normalizing effect on structural protein synthesis, thereby explaining prevention and repair of axonal degeneration.

Nerve fibre regeneration is impaired in Type I DNP and contributes to the progressive net fibre loss. It is a complex series of temporospatial events. Early immediate gene responses involving the sequential up-regulation of IGF-1, c-fos and NGF initiate this progression of events [40, 47]. Their delay and suppression in the diabetic BB/Wor rat [40] probably result in impaired nerve fibre regeneration $[46,47]$. In the intervention group, regenerating fibres were fourfold more numerous than at 5 months of diabetes, when axonal degeneration was fivefold greater than in control rats. After C-peptide treatment, these fibres were either repaired (normalization of axonal degeneration) or substituted by regenerated fibers as reflected by a normal fiber number in $\mathrm{D} 1 \mathrm{CP}-5 / 8$ rats, suggesting a neuroprotective effect by C-peptide.

In summary, replacement doses of C-peptide partially prevent the non-hyperglycaemic-induced metabolic, functional and structural changes in Type I DPN. C-peptide treatment of established Type I DPN results in functional improvement, structural repair, and promotion of fibre regeneration. We conclude that deficiency of insulinomimetic C-peptide plays a pathogenetic role in Type I DPN. While analogous findings in humans remain to be established, the results suggest that $\mathrm{C}$-peptide replacement in Type I diabetic patients could provide a valuable adjunct in preventing DPN.

Acknowledgements. These studies were supported by the Thomas Foundation, Bloomfield Hills, Mich., U.S.A. (AAFS) and the Juvenile Diabetes Foundation (AAFS, KS).

\section{References}

1. Greene DA, Sima AAF, Stevens M et al. (1993) Aldose reductase inhibitors: An approach to the treatment of the nerve damage of diabetic neuropathy. Diabetes Metabol Rev 9: 189-217

2. Low PA, Lagerlund TD, McManis PG (1989) Nerve blood flow and oxygen delivery in normal, diabetic and ischemic neuropathy. Int Rev Neurobiol 31: 355-438

3. Stevens MJ, Dananberg J, Feldman EL et al. (1994) The linked roles of nitric oxide, aldose reductase and $(\mathrm{Na}+1$ $\mathrm{K}+$ )-ATPase in the slowing of nerve conduction in the streptozotocin diabetic rat. J Clin Invest 94: 853-859 
4. Sima AAF, Ristic H, Merry A et al. (1996) The primary preventional and secondary interventative effects of acetyl-L-carnitine on diabetic neuropathy in the BB/W-rat. J'Clin Invest 97: 1900-1907

5. Tomlinson DR, Fernyhough P (2000) Neurotrophism in diabetic neuropathy. In: Sima AAF (ed) Frontiers in Animal Diabetes Research. Chronic Complications in Diabetes. Harwood Acad Publ, Amsterdam. pp 167-182

6. Singleton JR, Dixit VM, Feldman EL (1996) Type-1 insulin-like growth factor receptor activation regulates apoptotic proteins. J Biol Chem 271: 31791-31794

7. Requena JR, Baynes JW (2000) Studies in animal models on the role of glycation and advanced glycation end-products (AGE's) in the pathogenesis of diabetic complications. In: Sima AAF (ed) Frontiers in Animal Diabetes Research. Chronic Complication in Diabetes. Harwood Acad Publ, Amsterdam. pp 43-69

8. Stevens MJ, Obrosova I, Cao X, van Huysen C, Greene DA (2000) Effects of DL- $\alpha$-lipoic acid on peripheral conduction, blood flow, energy metabolism and oxidative stress in experimental diabetic neuropathy. Diabetes 49: 1006-1015

9. Cameron NE, Cotter MA (2000) Oxidative stress and abnormal lipid metabolism in diabetic complications. In: Sima AAF (ed) Frontiers in Animal Diabetes Research. Chronic Complication in Diabetes. Harwood Acad Publ, Amsterdam. pp 97-130

10. Sima AAF, Sugimoto K (1999) Experimental diabetic neuropathy: an update. Diabetologia 42: 773-788

11. The Diabetes Control and Complications Trial Research Group (1993) The effect of intensive treatment of diabetes on development and progression of long-term complications in insulin-dependent diabetes mellitus. N Engl J Med 329: 977-986

12. Yagihashi S, Sugimoto K, Wada R (1994) Different neuropathic patterns between type I and type II animal models. In: Sakamoto N, Alberti KGMM, Hotta N (ed) Pathogenesis and Treatment of NIDDM and its Related Problems. Elsevier, Amsterdam. pp 401-405

13. Sima AAF, Zhang W, Xu G, Sugimoto K, Guberski D, Yorek MA (2000) A comparison of diabetic polyneuropathy in type II diabetic BBZDR/Wor-rats and type I diabetic BB/Wor-rats. Diabetologia 43: 786-793

14. Sima AAF, Nathaniel V, Bril V, McEwen TAJ, Greene DA (1988) Histopathological heterogeneity of neuropathy in insulin-dependent and non-insulin-dependent diabetes, and demonstration of axo-glial dysjunction in human diabetic neuropathy. J Clin Invest 81: 349-364

15. Sima AAF, Lattimer SA, Yagihashi S, and Greene DA (1986) “Axo-glial dysjunction": A novel structural lesion that accounts for poorly reversible slowing of nerve conduction in the spontaneously diabetic BB-rat. J Clin Invest 77: 474-484

16. Dyck PJ, Davies JL, Wilson DM, Service FJ, Meton LJ III, O’Brien PC (1999) Risk factors for severity of diabetic polyneuropathy. Diabetes Care 22: 1479-1486

17. Wang C, Li Y, Wible B, Angelides KJ, Ischii DN (1992) Effects of insulin and insulin-like growth factors on neurofilament mRNA and tubulin mRNA content in human neuroblastoma SH-Y5Y cells. Brain Res Mol Brain Res 13: 289-300

18. Ido Y, Vindigni A, Chang K et al. (1997) Prevention of vascular and neural dysfunction in diabetic rats by C-peptide. Science 777: 563-566

19. Johansson B-L, Borg K, Fernquist-Forbes E, Odergren T, Remahl S, Wahren J (1996) C-peptide improves autonomic nerve function in patients with Type I diabetes. Diabetologia 39: 687-695
20. Johansson B-L, Borg K, Fernquist-Forbes E, Kernell A, Odergren T, Wahren J (2000) Beneficial effects of C-peptide on incipient nephropathy and neuropathy in patients with Type I diabetes - a three month study. Diabet Med 17: $181-189$

21. Stevens MJ, Henry DN, Thomas TP, Killen PD, Greene DA (1993) Aldose reductase gene expression and osmotic dysregulation in cultured human retinal pigment epithelial cells. Am J Physiol 265: E228-E238

22. Yamamoto K, Merry AC, Sima AAF (1996) An orderly development of paranodal axoglial junctions and bracelets of Nageotte in the rat sural nerve. Brain Res Develop Brain Res 96: 36-45

23. Steiner D, Cunningham D, Spigelman L, Aten B (1967) Insulin biosynthesis: evidence for a precursor. Science 157: 697-700

24. Ohtomo Y, Aperia A, Sahlgren B, Johansson B-L, Wahren $\mathrm{J}$ (1996) C-peptide stimulates rat renal tubular $\mathrm{Na}^{+}, \mathrm{K}^{+} \mathrm{AT}$ Pase activity in synergism with neuropeptide Y. Diabetologia 39: 199-205

25. Wahren J, Ekberg K, Johansson J et al. (2000) Role of Cpeptide in human physiology. Am J Physiol 278: 759-768

26. Rigler R, Pramanik A, Jonasson P et al. (1999) Specific binding of proinsulin C-peptide to human cell membranes. Proc Natl Acad Sci USA 96: 13318-13323

27. Li Z-G, Qiang X, Sima AAF, Grunberger G (2001) C-peptide attenuates protein tyrosine phosphatase activity and enhances glycogen synthesis in L6 myoblasts. Biochem Biophys Res Commun 280: 615-619

28. Brismar T, Sima AAF (1981) Changes in nodal function in nerve fibers of the spontaneously diabetic BB-Wistar rat. Acta Physiol Scand 113: 499-506

29. Sima AAF, Brismar T (1985) Reversible diabetic nerve dysfunction. Structural correlates to electrophysiological abnormalities. Ann Neurol 18: 21-29

30. Stevens EJ, Carrinton AL, Tomlinson DR (1994) Nerve ischemia in diabetic rats: time course of development, effect of insulin treatment plus comparison of streptozotocin and BB models. Diabetologia 37: 43-44

31. Jensen ME, Messina EJ (1999) C-peptide induces concentration-dependent dilation of skeletal muscle arterioles only in the presence of insulin. Am J Physiol 276: H1223-H1228

32. Sima AAF, Prashar A, Zhang W-X, Chakrabarti S, Greene DA (1990) Preventive effect of long-term aldose reductase inhibition (Ponalrestat) on nerve conduction and sural nerve structure in the spontaneously diabetic BB-rat. J'Clin Invest 85: 1410-1420

33. Sugimoto K, Murakawa Y, Zhang W, Xu G, Sima AAF (2000) Insulin receptor in rat peripheral nerve: its localization and alternatively spliced isoforms. Diabetes Metab Res Rev 16: 354-363

34. Kordeli E, Lambert S, Bennett V (1995) Ankyrin G: A new ankyrin gene with neural-specific isoforms localized at the axonal initial segment and node of Ranvier. J Biol Chem 5: 2352-2359

35. Einheber S, Zanazzi G, Ching W et al. (1997) The axonal membrane protein Caspr, a homologue of neurexin $\mathrm{IV}$, is a component of the septate-like paranodal junctions that assemble during myelination. J Cell Biol 139: 1495-1506

36. Poliak S, Gollan L, Martinez R et al. (1999) Caspr 2, a new member of the neurexin superfamily is localized at the juxtaparanodes of myelinated axons and associated with $\mathrm{K}^{+}$channels. Neuron 24: 1037-1047

37. Peles E, Nativ M, Lustig M et al. (1997) Identification of a novel contactin-associated transmembrane receptor with 
multiple domains implicated in protein-protein interactions. EMBO J 16: 978-988

38. Cherian PV, Kamijo M, Angelides KJ, and Sima AAF (1996) Nodal $\mathrm{Na}^{+}$channel displacement is associated with nerve conduction slowing in the chronically diabetic $\mathrm{BB} /$ W-rat. Prevention by an aldose reductase inhibitor. J Diabetes Complication 10: 192-200

39. Ishii DN, Lupien SB (1995) Insulin-like growth factors protect against diabetic neuropathy: effects on sensory nerve regeneration in rats. J Neurosci Res 40: 138-144

40. Xu G (2000) Neurotrophic factors and other growth factors in diabetic nerve regeneration. [Thesis] Wayne State University, Detroit

41. Fernybrough P, Carrington AL, Tomlinson DR (1992) Reduced nerve growth factor mRNA in skin of diabetic rats: effects of insulin. Br J Pharmacol 107: 462P

42. Verge VMK, Tetzlaff W, Bisby MA, Richardson PM (1990) Influence of nerve growth factor on neurofilament gene expression in mature primary sensory neurons. J Neurosci 10: 2018-2025
43. Wang C, Li Y, Wible B, Angelides KJ, Ischii DN (1992) Effect of insulin and insulin-like growth factors on neurofilament mRNA and tubulin mRNA content in human neuroblastoma SH-Y5Y cells. Brain Res Mol Brain Res 13: 289-300

44. Yagihashi S, Kamijo M, Watanabe K (1990) Reduced myelinated fiber size correlates with loss of axonal neurofilaments in peripheral nerve of chronically streptozotocin diabetic rats. Am J Pathol 136: 1365-1373

45. Hengerer B, Lindholm D, Hermann R, Ruther V, Wagner EF, Thoenen H (1990) Lesion-induced increase in nerve growth factor mRNA is mediated by c-fos. Proc Natl Acad Sci USA 87: 3899-3903

46. Sima AAF, Merry AC, Lightle R (1997) Impaired macrophage recruitment in axotomized diabetic nerve. Exp Clin Endocrinol Diabetes 105: 62-63

47. Kamijo M, Merry AC, Cherian PV, Akdas G, Sima AAF (1996) Nerve fiber regeneration following axotomy in the diabetic BB/W-rat. The effect of ARI treatment. J Diabetes Complications 10: 183-191 